\title{
PENETAPAN KADAR VITAMIN C DENGAN SPEKTROFOTOMETRI UV-VIS PADA BERBAGAI VARIASI BUAH TOMAT
}

\author{
Asiska Permata Dewi \\ 1) D III Analis Farmasi dan makanan, FKIK Universitas Abduurab \\ Jl. Riau ujung No 76 Pekanbaru Indonesia \\ email : asiska.permata@univrab.ac.id
}

\begin{abstract}
Tomato is a kind of fruit containing vitamin C. Vitamin $C$ is needed for collagen production, bone and teeth formation, wound healing, and immunity to infection. This vitamin is dissolve in water and easy to be destroyed by light and high temperature, so the storage and condition of tomato fruits need special attention to keep an adequate vitamin $C$ level it contained. This research aimed to determine the level of vitamin $C$ in three kinds tomato fruits maturation degree: raw, half-mature, and mature. The quantification was conducted using spectrophotometry UVVis method with maximum wave length of $265 \mathrm{~nm}$ and absorbance of $0.475(Y=0.0557 X+0.0789)$. The result showed that the average level of vitamin $C$ in raw, half-mature, and mature tomato was 74.03666; 53.81333; and $43.56666 \mathrm{mg} / 100 \mathrm{~g}$, respectively. In conclusion, the level of vitamin C in raw tomato was the highest among all samples.
\end{abstract}

Keywords : Vitamin C, tomato fruit, spectrophotometry UV-Vis.

\section{ABSTRAK}

Tomat merupakan salah satu buah yang mengandung vitamin C. Vitamin ini diperlukan untuk produksi kolagen, pembentukan tulang dan gigi, penyembuhan luka dan kekebalan terhadap infeksi. Vitamin C merupakan vitamin larut air yang mudah rusak oleh udara sehinnga kondisi buah tomat harus diperhatikan agar mendapatkan kandungan vitamin yang cukup. Penelitian ini bertujuan untuk mengetahui kadar vitamin $\mathrm{C}$ pada buah tomat muda, tomat setengah masak dan tomat masak. Metode yang digunakan adalah Spektrofotometri UV-Vis. Panjang gelombang maksimum vitamin C yang didapat yaitu $265 \mathrm{~nm}$ dengan absorban 0,475 , maka persamaan regresi linier adalah $\mathrm{Y}=0,0557 \mathrm{X}+0,0789$. Hasil penelitian kandungan vitamin $C$ pada buah tomat muda adalah 74,03666 mg/100 g, tomat setengah masak adalah 53,81333 $\mathrm{mg} / 100 \mathrm{~g}$ dan tomat masak adalah 43,56666 mg/100g. Berdasarkan hasil penelitian menunjukkan bahwa kadar vitamin $\mathrm{C}$ pada buah tomat muda lebih tinggi dibandingkan dengan tomat setengah masak dan tomat masak.

Kata kunci : Vitamin C, buah tomat, Spektrofotometri UV-Vis.

\section{Pendahuluan}

Vitamin adalah senyawa organik yang sangat dibutuhkan oleh tubuh manusia untuk mempertahankan kehidupan dan kesehatan walaupun hanya dalam jumlah yang sedikit. Vitamin terdiri dari dua jenis, yaitu vitamin yang larut dalam air dan vitamin yang larut dalam lemak (1). Vitamin larut air biasanya tidak disimpan di dalam tubuh dan dikeluarkan melalui urin. Oleh sebab itu vitamin larut air perlu dikonsumsi tiap hari untuk mencegah kekurangan yang dapat mengganggu fungsi tubuh normal. Vitamin $\mathrm{C}$ (asam askorbat) adalah salah satu jenis vitamin yang larut air dan memiliki peranan penting di dalam tubuh, sebagai koenzim atau kofaktor. Fungsi vitamin $\mathrm{C}$ banyak berkaitan dengan pembentukan kolagen yang merupakan senyawa protein yang mempengaruhi integritas struktur sel di semua jaringan ikat, seperti pada tulang rawan, gigi, membran kapiler, kulit dan urat otot. Dengan demikian, vitamin C berperan dalam penyembuhan luka, patah tulang, memelihara kesehatan gigi dan gusi (2).

Tomat merupakan salah satu buah yang mengandung vitamin C. Dalam kehidupan sehari-hari tomat memegang peranan penting, terutama bagi ibu-ibu rumah tangga yang sering menggunakan tomat sebagai 
masakan seperti membuat sambal, sup, salad, dan minuman seperti jus. Tomat juga bisa dimakan langsung dengan warna merah merakah, rasa yang segar dan manis agak kemasam-masaman (3). Tomat dapat digolongkan sebagai sumber vitamin $\mathrm{C}$ yang unggul, karena 100 gram tomat dapat memenuhi $20 \%$ atau lebih kebutuhan vitamin C sehari (4). Kadar vitamin C buah tomat segar (dari tiap $100 \mathrm{~g}$ buah) menurut Direktorat Gizi Departemen Kesehatan RI tahun 1972 adalah 40 mg (3).

Fungsi vitamin $\mathrm{C}$ di dalam tubuh bersangkutan dengan sifat alamiahnya sebagai antioksidan. Vitamin $\mathrm{C}$ juga berperan serta di dalam banyak proses metabolisme yang berlangsung di dalam jaringan tubuh (5). Menurut Almatsier (2004), beberapa fungsi vitamin C adalah sebagai sintesis kolagen, karnitin, noradrenalin, serotonin. Selain itu, untuk absorbs dan metabolism zat besi, kalsium, mencegah infeksi, kanker, dan penyakit jantung.

Angka kecukupan gizi yang dianjurkan untuk vitamin C pada anak-anak adalah $45 \mathrm{mg}$ sedangkan pada orang dewasa adalah $60 \mathrm{mg}$. Kekurangan vitamin $\mathrm{C}$ dapat menyebabkan penyakit skorbut dengan gejala lelah, lemas, napas pendek, kejang otot, kulit menjadi kering dan gatal, perdarahan gusi, mulut dan mata kering, rambut rontok, dan juga dapat menyebabkan luka sukar sembuh, terjadi anemia, defresi dan gangguan saraf (2). Dengan demikian, penulis ingin mengetahui dan membandingkan kadar vitamin C pada buah tomat yang muda, setengah masak, dan masak menggunakan spektrofotometri UV-Vis.

Vitamin $\mathrm{C}$ disebut juga dengan asam askorbat, yang merupakan vitamin larut air yang berbentuk kristal putih, merupakan suatu asam organic dan terasa asam, tetapi tidak berbau (5). Dari semua vitamin yang ada, vitamin $\mathrm{C}$ merupakan vitamin yang paling mudah rusak. Di samping sangat larut dalam air, vitamin $\mathrm{C}$ mudah teroksidasi dan proses tersebut dipercepat oleh panas, sinar, alkali, enzim, oksidator, serta oleh katalis tembaga dan besi. Vitamin $\mathrm{C}$ dapat terserap dengan cepat dari alat pencernaan kita masuk kedalam saluran darah dan dibagikan keseluruh jaringan tubuh. Bila seseorang mengkonsumsi vitamin $\mathrm{C}$ dalam jumlah besar maka akan dibuang keluar terutama bila orang tersebut biasa mengkonsumsi makanan yang bergizi tinggi, tetapi sebaliknya, bila orang tersebut jelek keadaan gizinya maka sebagian besar jumlah itu dapat ditahan oleh jaringan tubuh (6).

\section{Tinjauan Pustaka}

Vitamin adalah senyawa organik yang sangat dibutuhkan oleh tubuh manusia. Pada umumnya tubuh manusia tidak mampu membentuk vitamin sendiri (kecuali vitamin D dan K), untuk itu agar tubuh dapat terpenuhi kebutuhanakan vitamin, individu harus mendapatkan dari makanan. Vitamin berperan sebagai katalisator organik, di tubuh vitamin mempunyai peran utama sebagai zat pengatur berbagai metabolisme, pembentukan sel-sel baru dan pertumbuhan, mempertahankan fungsi sebagai jaringan tubuh, membantu pembentukan zat-zat tertentu dalam tubuh, dan pembangun bersama zat gizi lain melalui pembentukan enzim, antibodi, dan hormon (1)

Vitamin $\mathrm{C}$ disebut juga dengan asam askorbat, yang merupakan vitamin larut air yang berbentuk kristal putih, merupakan suatu asam organic dan terasa asam, tetapi tidak berbau (5). Dari semua vitamin yang ada, vitamin $\mathrm{C}$ merupakan vitamin yang paling mudah rusak. Di samping sangat larut dalam air, vitamin $\mathrm{C}$ mudah teroksidasi dan proses tersebut dipercepat oleh panas, sinar, alkali, enzim, oksidator, serta oleh katalis tembaga dan besi. Vitamin $\mathrm{C}$ dapat terserap dengan cepat dari alat pencernaan kita masuk kedalam saluran darah dan dibagikan keseluruh jaringan tubuh. Bila seseorang mengkonsumsi vitamin $\mathrm{C}$ dalam jumlah besar maka akan dibuang keluar terutama bila orang tersebut biasa mengkonsumsi makanan yang bergizi tinggi, tetapi sebaliknya, bila orang tersebut jelek keadaan gizinya maka sebagian besar jumlah itu dapat ditahan oleh jaringan tubuh (6).

\section{Sumber Vitamin C}

Vitamin C terutama ditemukan dalam sayuran dan buah-buahan yang segar. Sumber terbaiknya adalah jeruk, jambu, gandaria, manga, tomat, dan sayuran seperti bayam, daun pepaya, daun singkong, sawi dan lain-lain. Nasi tidak mengandung vitamin $\mathrm{C}$ sedangkan kentang dan ketela mengandung sedikit vitamin $\mathrm{C}$ sehingga orang yang makannya tidak bervariasi dan hanya mengandalkan makanan pokok nasi saja 
mungkin akan kekurangan vitamin ini.

\section{Fungsi Vitamin C}

Fungsi vitamin $\mathrm{C}$ di dalam tubuh bersangkutan dengan sifat alamiahnya sebagai antioksidan. Vitamin $\mathrm{C}$ juga berperan serta di dalam banyak proses metabolisme yang berlangsung di dalam jaringan tubuh (5). Menurut Almatsier (2004), beberapa fungsi vitamin C adalah sebagai sintesis kolagen, karnitin, noradrenalin, serotonin. Selain itu, untuk absorbs dan metabolism zat besi, kalsium, mencegah infeksi, kanker, dan penyakit jantung.

Tomat

Tomat (Lycopersicum esculentum) termasuk buah-buahan atau sayuran yang paling populer bagi masyarakat Indonesia. Varietas tomat sangat banyak, ada yang ukurannya sebesar telur puyuh, ada pula ukurannya hingga sebesar telur angsa. Warnanya pun bervariasi, yaitu merah, kuning, orange, hijau, dan cokelat. Banyak alasan yang membuat konsumsi tomat di masyarakat sangat tinggi, misalnya karena rasa, ketersediaannya yang berlimpah, serta harga yang relatif murah. Namun, jarang yang menyadari bahwa konsumsi tomat secara rutin bermanfaat besar bagi kesehatan.

\section{Metode Penelitian}

\section{Desain Penelitian}

Desain penelitian ini adalah deskriptif yaitu untuk mengetahui kadar vitamin $\mathrm{C}$ pada berbagai buah tomat (muda, setengah masak, dan masak). Pengujian dilakukan sebanyak 3 kali pengulangan menggunakan spektrofotometri UV-Vis.

Pembuatan Larutan Induk Vitamin C 100 ppm

Vitamin C ditimbang sebanyak 0,05 g kemudian dimasukkan kedalam labu ukur $500 \mathrm{ml}$ yang telah dibungkus alumunium foil dan dilarutkan dengan akuades sampai tanda batas dan dihomogenkan sehingga di dapatkan konsentrasi 100 ppm.

\section{Pembuatan Larutan Kurva Kalibrasi}

Dipipet larutan vitamin C 100 ppm kedalam labu ukur $100 \mathrm{ml}$ yang telah dibungkus alumunium foil masing-masing sebesar $3 \mathrm{ml}, 5 \mathrm{ml}, 7 \mathrm{ml}, 9 \mathrm{ml}$, dan $11 \mathrm{ml}$. Lalu ditambahkan akuades hingga tanda batas dan dihomogenkan .sehingga di dapatkan konsentrasi 3 ppm, 5 ppm, 7 ppm, 9 ppm dan 11 ppm.

Penentuan Panjang Gelombang Maksimum Larutan Vitamin C

Diambil larutan konsentrasi 7 ppm dari larutan kurva kalibrasi lalu dimasukkan kedalam kuvet, selanjutnya di ukur pada panjang gelombang 200-400 nm dengan menggunakan blanko akuades.

\section{Pengukuran Larutan Kurva Kalibrasi}

Diukur absorbansi masing-masing larutan kurva kalibrasi 3 ppm, 5 ppm, 7 ppm, 9 ppm, dan 11 ppm lalu dimasukkan kedalam kuvet, selanjutnya diukur absorbansi pada panjang gelombang maksimum yang diperoleh. Setelah itu dibuat kurva kalibrasi dan dihitung persamaan regresi linear dari data yang diperoleh.

\section{Penentuan Kadar Vitamin C pada Daging Buah Tomat Muda Tomat Setengah Masak dan Tomat Masak}

Buah tomat diambil dan bijinya dibuang, dipotong-potong kecil dan digerus halus. Dibuat larutan sampel dengan cara ditimbang sebanyak $50 \mathrm{~g}$ dan dilarutkan dengan akuades dalam beaker glass. Kemudian dimasukkan kedalam labu ukur $100 \mathrm{ml}$, lalu ditambahkan akuades hingga tanda batas dan homogenkan. Setelah itu larutan sampel disaring menggunakan kertas saring. Larutan sampel yang didapat di pipet sebanyak $2 \mathrm{ml}$ dalam labu ukur $50 \mathrm{ml}$. Penentuan kadar vitamin C pada sampel dilakukan dengan cara larutan sampel dimasukkan kedalam kuvet dan diukur absorbansi pada panjang gelombang maksimum yang didapat lalu dihitung kadar vitamin $\mathrm{C}$ dengan memasukkan nilai absorbansi kedalam persamaan regresi linear.

\section{Analisis Data}


Analisa data dilakukan dengan absorbansi sampel kekurva kalibrasi dengan menggunakan persamaan regresi linear $\mathbf{Y}=\mathbf{B X}+$ A. Persamaan ini digunakan untuk menghitung kadar vitamin C dalam sampel. Dimana (Y) menyatakan nilai pengukuran absorbansi dan $(\mathrm{X})$ menyatakan kadar vitamin $\mathrm{C}$ dalam sampel. Hasil dan Pembahasan

Penelitian ini dilakukan untuk mengetahui kadar vitamin $\mathrm{C}$ yang terkandung dalam buah tomat muda, tomat setengah masak dan tomat masak. Alasan memilih 3 jenis tomat adalah karena banyak masyarakat yang menjual buah tomat yang muda, tomat setengah masak dan tomat masak yang tidak diketahui bahwa buah tomat yang mana yang lebih tinggi kadar vitamin $\mathrm{C}$ dan disamping rasanya yang cukup enak, tomat juga mudah dijangkau dan relatif murah. Penelitian ini dilakukan dengan menggunakan spektrofotometri UV-Vis. Spektrofotometri UV-Vis adalah metode analisis pengukuran konsentrasi suatu senyawa berdasarkan kemampuan senyawa tersebut mengabsorbsi berkas sinar atau cahaya yang menghasilkan sinar monokromatis dalam jangkauan panjang gelombang 200-400 nm (7).

Penelitian ini terlebih dahulu dilakukan pencarian panjang gelombang maksimum. Panjang gelombang maksimum adalah panjang gelombang dimana suatu zat memberikan penyerapan paling tinggi. Alasan penggunaan panjang gelombang maksimum yaitu pada panjang gelombang maksimum kepekaannya maksimal karena pada panjang gelombang maksimum tersebut perubahan absorbansi untuk setiap satuan konsentrasi adalah yang paling besar, disekitar panjang gelombang maksimum bentuk kurva absorbansi datar dan pada kondisi tersebut hukum Lambert-Beer akan terpenuhi, dan jika dilakukan pengukuran ulang maka kesalahan yang disebabkan oleh pemasangan ulang panjang gelombang akan kecil sekali (7).

Dari penelitian yang telah dilakukan, panjang gelombang maksimum larutan baku vitamin C yaitu $265 \mathrm{~nm}$ dengan nilai absorbansi 0,475 . Panjang gelombang yang didapat sudah sesuai dengan literatur yaitu panjang gelombang maksimum vitamin C adalah $265 \mathrm{~nm}$ (Gambar 1). Panjang gelombang memiliki batas toleransi yang diperbolehkan yaitu kurang lebih $1 \mathrm{~nm}$ untuk jangkauan 200-400 nm (8).

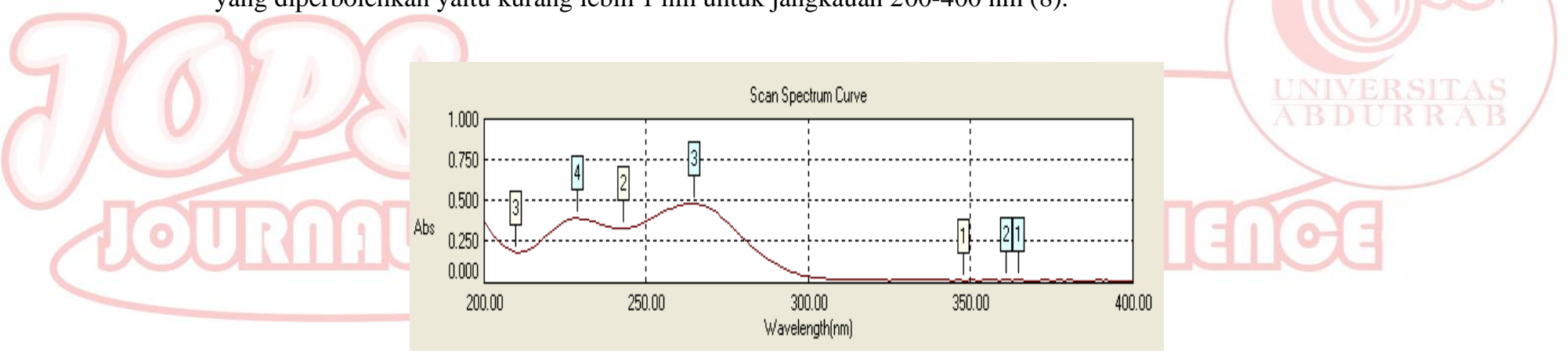

Gambar 1. pengukuran spektrum panjang gelombang maksimum vitamin C

Kegiatan selanjutnya adalah membuat deret larutan sandar vitamin C yaitu 3 ppm, 5 ppm, 7 ppm, 9 ppm, $11 \mathrm{ppm}$. Kemudian diukur salah satu larutan yaitu $7 \mathrm{ppm}$ untuk mengetahui panjang gelombang maksimum larutan baku vitamin $\mathrm{C}$ tersebut. Kemudian deret larutan diukur absorbansinya pada panjang gelombang maksimum yang diperoleh dengan menggunakan blanko akuades. Blanko bertujuan untuk mengatur spektrofotometer hingga pada panjang gelombang pengukuran mempunyai serapan nol. Vitamin $\mathrm{C}$ dapat diukur dengan menggunakan spektrofotometri UV-Vis pada panjang gelombang 200-400 nm karena vitamin C memiliki struktur molekul kromofor yang dapat menyerap sinar UV (9).

Dari hasil perhitungan regresi linier didapat persamaan yaitu $\mathrm{Y}=0,0557 \mathrm{X}+0,0789$ dengan koefisien korelasi (r) sebesar 0,99975. Kriteria penerimaan dan koefisien korelasi (r) sebesar $r>0,99$ yang menunjukkan linieritas yang sangat baik yang berarti bahwa hasil kurva antara absorban dan konsentrasi, nilai absorban juga meningkat (10).

Nilai absorban masing-masing adalah pada tomat muda 0,$757 ; 0,760 ; 0,723$, pada tomat setengah masak adalah 0,$538 ; 0,522 ; 0,502$ dan pada tomat masak adalah 0,$440 ; 0,401 ; 0,379$. Hasil rata-rata kadar vitamin $\mathrm{C}$ yang terkandung dalam buah tomat muda, tomat setengah masak dan tomat masak berturut-turut 
adalah 74,03666 mg/100g; 53,81333 mg/100g; 43,56666 mg/100g. Menurut literatur kadar vitamin C pada buah tomat muda dan tomat masak berturut-turut adalah $23,4 \mathrm{mg} / 100 \mathrm{~g}, 17,6 \mathrm{mg} / 100 \mathrm{~g}$. Dari hasil yang didapat maka kadar vitamin $\mathrm{C}$ pada buah tomat muda lebih tinggi dibandingkan dengan buah tomat setengah masak dan tomat masak. Hal ini dikarenakan bahwa buah yang masih mentah lebih banyak mengandung vitamin $C$, semakin tua buah semakin berkurang vitamin $C$ yang terkandung dalam buah tersebut (6).

\section{Kesimpulan}

Dari hasil penelitian dapat disimpulkan bahwa kadar vitamin C yang terdapat pada buah tomat muda adalah $74,03666 \mathrm{mg} / 100 \mathrm{~g}$, tomat setengah masak adalah 53,81333 mg/100g dan tomat masak adalah 43,56666 $\mathrm{mg} / 100 \mathrm{~g}$. Hasil ini menunjukkan bahwa kadar vitamin $\mathrm{C}$ pada buah tomat muda lebih tinggi dibandingkan dengan buah tomat setengah masak dan tomat masak.

\section{Referensi}

1. Widuri, H., dan Dedi, M.P. 2013. Komponen Gizi dan Bahan Makanan untuk Kesehatan. Yogyakarta

2. Almatsier, S. 2004. Prinsip Dasar Ilmu Gizi. Jakarta: PT Gramedia Pustaka Utama

3. Tugiyono, H. 1999. Bertanam Tomat. Jakarta: PT Penebar Swadaya

4. Astawan, M. 2009. Ensiklopedia Gizi Pangan. Jakarta: PT Diam Rakyat

5. Jauhari, A. 2013. Dasar-dasar Ilmu Gizi. Yogjakarta

6. Winarno, F. G. 2004. Kimia Pangan dan Gizi. Jakarta: PT Gramedia Pustaka Utama

7. Gandjar, I.G., dan A. Rohman. 2012. Analisis Obat Secara Spektrofotometri dan Kromatografi. Yogjakarta: Pustaka Pelajar

8. Departemen Kesehatan Republik Indonesia. 1995. Farmakope Indonesia, Edisi IV. Jakarta

9. Karinda, M., Fatmawati dan Citraningtyas, G. 2013. Perbandingan Hasil Penetapan Kadar Vitamin C Mangga Dodol Dengan Menggunakan Metode Spektrofotometri UV-Vis dan Iodometri. Jurnal Ilmiah Farmasi. Unsrat Manado. Volume 2, No.01:86-89

10. Lestari, S., dan P. I. Utami. 2011. Analisis Natrium Nitrit secara Spektrofotometri Visibel dalam Daging Burger yang Beredar di Swalayan Purwokerto.Jurnal Pharmacy. Volume 8: 95 


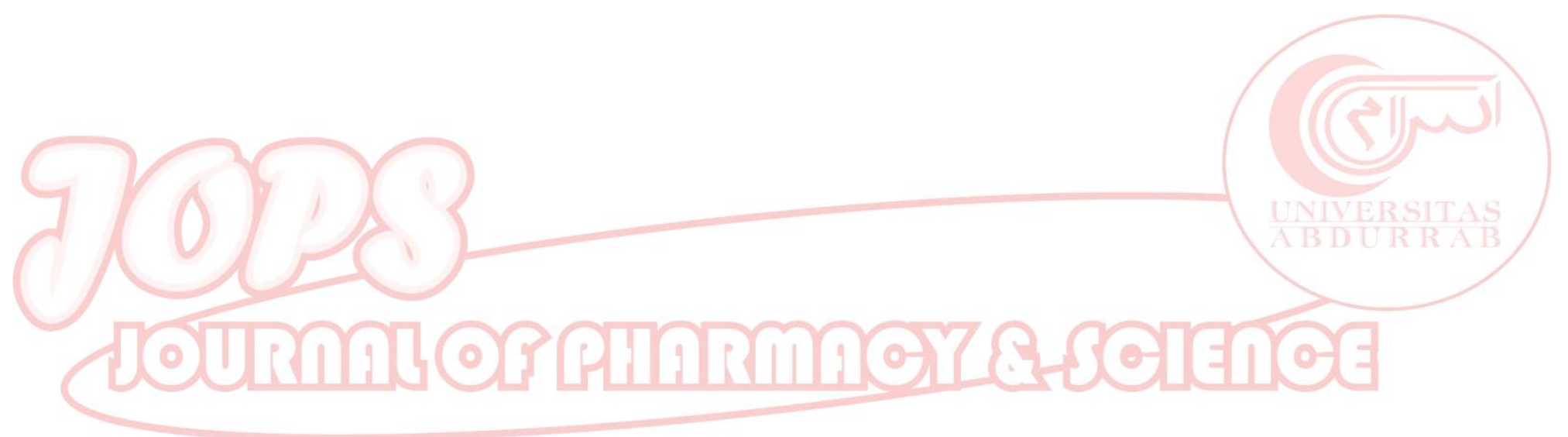

